\title{
Analiza petrograficzna narzutniaków w żwirowni Łubienica-Superunki oraz ich skandynawskie obszary alimentacyjne
}

\author{
Maria Górska-Zabielska ${ }^{1}$, Ewa Smolska ${ }^{2}$, Lucyna Wachecka-Kotkowska ${ }^{3}$
}

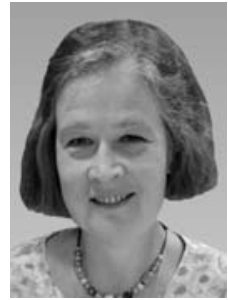

M. Górska-

-Zabielska

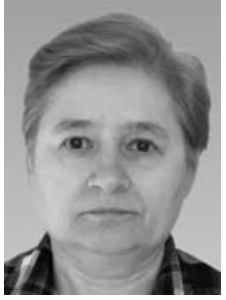

E. Smolska

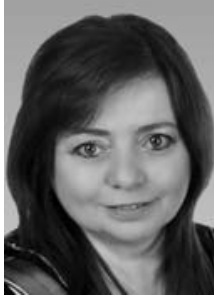

L. Wachecka-Kotkowska

Petrographic analysis of erratics in the Lubienica-Superunki gravel pit and their Scandinavian source areas. Prz. Geol., 69: 43-54; doi: 10.7306/2021.4

A b s t r a c t. Petrographic studies covered 20-60 $\mathrm{mm}$ coarse gravel and 4-10 mm medium-grained fractions of two till horizons (units $Ł S$ II and $€ S I V$ ) and two beds of sand-gravelly-outwash deposits(units $E S I$ and $E S$ III) associated with the Odra Glaciation (MIS6) in Eubienica-Superunki on the North Mazovian Lowland. Regardless of the facies type and grain sise, crystalline rocks dominate over all other petrographic groups in all samples. The percentage of crystalline rocks is greater among coarse gravel (average $74.7 \%$ ) than among medium-grain gravel (average 67.8\%). The share of carbonate rocks is limited only to the both lower units $E S I$ and $E S$ II. The upper units ( $E S I I I$ and $Ł S I V$ ) are deprived of these rocks, both in the medium and coarse gravel fraction. Sandstones, presented in all samples, were in the range of 5-20\%. From the other petrographic groups, individual chalk limestones clasts, dolomites, flints and quartz grains were identified in the material. The indicator erratics were identified in all four units. Their percentage content stands for 10-18\% of the total sample of coarse-grained fraction. Among them, the most common were the erratics derived from the Aland Islands, and then from the area of south-eastern Sweden (Smailand) and from Dalarna in central Sweden. Amongst the erratics with limited indicator significance, Lower Paleozoic limestones and Jotnian sandstones were most frequent. Single fragments of Ordovician red and Paleoporella limestone were present. These rocks, including the Lower Paleozoic grey limestone, occurred only in the lower units (ES I and ES II). The results of the research suggest that the two lower sediment units should be correlated with a ice-sheet advance (Middle Polish Complex, Odranian Stadial?), and the two upper ones - with a separate, subsequent advancement (Wartanian?). The paper is another methodological contribution to the consideration of abandoning the tedious testing of glacial till and focusing on a much faster petrographic analysis of fluvioglacial sediments associated with the same ice sheet. This is demonstrated by the comparable results of the petrographic analysis of short transport outwash sediments and till from a single glacial period.

Keywords: petrographic analysis, Fennoscandian erratics, Saalian, Odranian and Wartanian stadials, MIS6, North Mazovian Lowland

Stanowisko w Łubienicy-Superunkach leży na wysokości 89-104 m n.p.m. w obrębie płaskiej wysoczyzny polodowcowej (52 $\left.37^{\circ} 52.756 " \mathrm{~N} ; 21^{\circ} 5^{\prime} 34.578^{\prime \prime E}\right)$ na Nizinie Północnomazowieckiej, na pograniczu Doliny Dolnej Narwi i Wysoczyzny Ciechanowskiej (Solon i in., 2018) (ryc. 1, 2). Odsłaniają się w nim dwie warstwy glin lodowcowych i dwie serie wodnolodowcowe, które są zapisem dwuetapowego odpływu sandrowego (Giriat i in., 2017). Osady piaszczysto-żwirowe są rozdzielone gliną zdeponowaną najprawdopodobniej w czasie zlodowacenia odry (Zabielski, 2006) lub starszego dolnego stadiału zlodowacenia warty (Kucharska, Pochocka-Szwarc，2012; Frankiewicz, 2017; Marcinkowski, 2017). Frankiewicz (2017) łączy warstwy górne $\mathrm{z}$ nasunięciem i recesją środkowego stadiału zlodowacenia warty. Dawniej górną serię wodnolodowcową, glinę i osady pokrywowe wiązano z nasuwaniem się i następnie recesją fazy wierzbickiej stadiału warty zlodowacenia środkowopolskiego (Nowak, 1969). Obecnie w ramach kompleksu środkowopolskiego, w jego górnej (najmłodszej) części wy- różnia się zlodowacenie odry ze stadiałem maksymalnym i warty (Ber i in., 2007; Marks i in., 2016).

Podczas wykonywania badań na obszarze arkusza Serock Szczegółowej Mapy Geologicznej Polski w skali 1 : 50000 (SMGP) (Nowak, 1969) złoże w Łubienicy-Superunkach nie było znane, ani tym bardziej eksploatowane. Stąd w opracowaniu Nowak (1969) nie ma informacji o tym stanowisku. Autorka wyróżniła zaledwie trzy typy petrograficzne w glinie lodowcowej odsłaniającej się w strefie

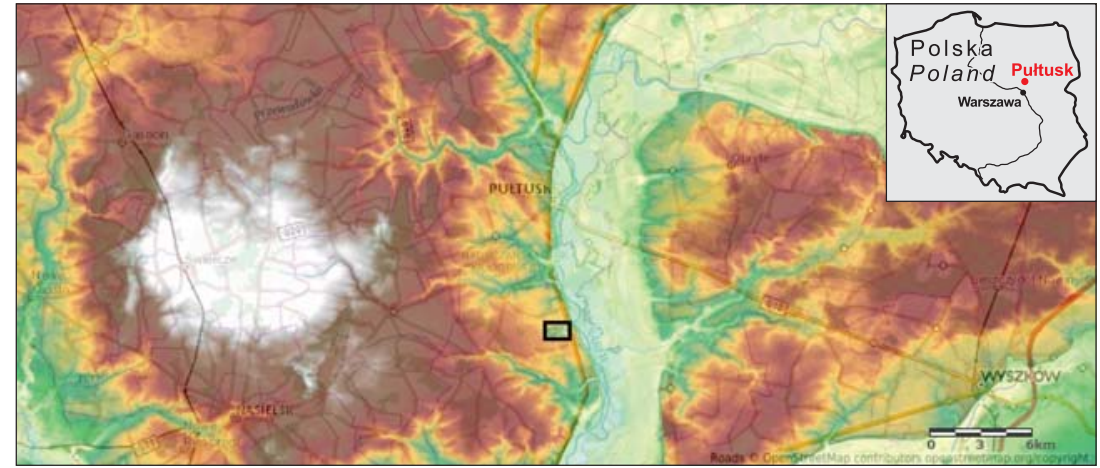

Ryc. 1. Cyfrowy model terenu badań (zaznaczony prostokątem) (geoportal.gov.pl) Fig. 1. Digital model of the research area (marked with a rectangle) (geoportal.gov.pl)

\footnotetext{
${ }^{1}$ Uniwersytet Jana Kochanowskiego, ul. Uniwersytecka 7, 25-406 Kielce; maria.gorska-zabielska@ujk.edu.pl

${ }^{2}$ Uniwersytet Warszawski, Krakowskie Przedmieście 30,00-927 Warszawa; e.smolska@uw.edu.pl

${ }^{3}$ Uniwersytet Łódzki, Narutowicza 88, 90-139 Łódź; lucyna.wachecka@geo.uni.lodz.pl
} 
glacjomarginalnej środkowego stadiału zlodowacenia warty, w odległości ok. $6 \mathrm{~km}$ na południe od Łubienicy-Superunek. Przeprowadzenie badań osadów kompleksu środkowopolskiego (Ber i in., 2007; Marks i in., 2016) okazało się możliwe, gdy rozpoczęto wydobycie kruszywa w odkrywce. W związku z tym w 2017 r. wykonano pilotażowe prace badawcze (Górska-Zabielska, 2017) pod kątem składu petrograficznego frakcji średniożwirowej (4-10 mm) i grubożwirowej (20-60 mm) osadów odsłaniających się w złożu Łubienica-Superunki. Zbadano, z uwzględnieniem metodyki badań petrograficznych osadów lodowcowych (TGL 25 232, 1971; Rutkowski, 1995a, b; Schulz, 1996; Lüttig, 1997), pojedyncze próbki w jednej serii osadów wodnolodowcowych. Wyniki analiz rzuciły nowe światło na zagadnienie proweniencji materiału skandynawskiego znajdującego się na Nizinie Północnomazowieckiej.

Niewystarczająca ilość materiału badawczego skłoniła autorki do poszerzenia analizy o kolejne próbki osadu obu frakcji, tym razem zarówno w dwóch glinach lodowcowych, jak i w dolnej serii wodnolodowcowej. Celem bieżących badań jest analiza spektrum petrograficznego osadów średnio- i grubożwirowych zlodowacenia odry występujących w Łubienicy-Superunkach, uszczegóławiająca poprzednie badania. Metodycznie zaplanowane opróbowanie obu frakcji osadu dwóch różnych typów litologicznych pozwoliło odnieść się do zagadnienia zasadności przeprowadzania żmudnych analiz petrograficznych w osadzie deponowanym wprost ze stopy lądolodu (glina lodowcowa), a także wstępnie przesortowanym (osady wodnolodowcowe). Przeprowadzone badania składu petrograficznego osadów wodnolodowcowych i ich zastosowanie do interpretacji proweniencji osadów są kontynuacją wcześniejszych badań autorek (Górska, 2002, 2006; Górska-Zabielska, 2008; Górska-Zabielska, Wachecka-Kotkowska, 2014, 2015 wraz z literaturą).

Analizy petrograficzne osadów uzupełniają rozpoznanie chronostratygraficzne, które wykonano innymi metodami, np. fizykochemicznymi (Wachecka-Kotkowska, 2015; Tylmann i in., 2019), paleoekologicznymi (Wachecka-Kotkowska i in., 2018; Czubla i in., 2019). Analiza frakcji żwirowej w glinach jest standardową metodą badawczą wykonywaną w ramach SMGP, ale znane są i inne przykłady takich badań (m.in. Meyer, 1985, 1998, 2000, 2005; Lüttig, 1991; Böse, Górska, 1995; Kenig, 1998; Czubla i in., 2013; Nitychoruk i in., 2018). Określeniem wieku osadów zawierających narzutniaki przewodnie we frakcjach średnioi grubożwirowej zajmowało się wielu autorów (m.in. Meyer, 1983, 1998, 2000; Böse, Górska, 1995; Gałązka, 2004; Lüttig, 2004, 2005; Czubla i in., 2019). Autorki proponują korelację chronostratygraficzną także w badanym stanowisku. Wyniki analiz petrograficznych frakcji grubożwirowej umożliwiły wskazanie obszaru alimentacyjnego tej części lądolodu, której masy lodu dotarły po obszar badań.

\section{OGÓLNA CHARAKTERYSTYKA BADANYCH OSADÓW W ŻWIROWNI W LUBIENICY-SUPERUNKACH}

W żwirowni w Łubienicy-Superunkach odsłaniają się miąższe osady wodnolodowcowe piaszczysto-żwirowe, piaszczyste, miejscami żwirowo-piaszczyste oraz niewielkiej miąższości gliny lodowcowe. Cechy osadów wodnolodowcowych zostały omówione w pracach Giriat $\mathrm{i}$ in.
(2017) oraz Smolskiej i in. (2018). W badaniach uwzględniono dwie (A i B na ryc. 2) ściany żwirowni Łubienica-Superunki w jej południowej części.

W spagu odkrywki w żwirowni odsłania się dolna seria wodnolodowcowa (jednostka ŁS I; ryc. 3; tab. 1) (Giriat $\mathrm{i}$ in., 2017). W jej stropie Dąbski i in. (2017) stwierdzili obecność dużego klina złożonego, z pierwotnym wypełnieniem lodowo-piaszczystym. Zdaniem ww. autorów taka lokalizacja klina wskazuje na długie funkcjonowanie wieloletniej zmarzliny na przedpolu transgredującego lądolodu, wiązanego przez Frankiewicza (2017) ze starszym stadiałem zlodowacenia warty, oraz długą przerwę w akumulacji osadów wodnolodowcowych w tym miejscu. Powyżej zalega nieciagła warstwa dolnej gliny lodowcowej (jednostka ŁS II; ryc. 3; tab. 1). Ma ona lokalnie zredukowaną niewielką miąższość - ok. 0,5-1 m, która podczas prowadzonych badań była najlepiej widoczna w środkowej części żwirowni (ryc. 3).

Wyżej występuje górna seria wodnolodowcowa (jednostka ŁS III; ryc. 4; tab. 1). Jej osady piaszczyste i żwirowe są dobrze widoczne na ścianie A żwirowni (ryc. 2). Jest ona przykryta nieciagłłą warstwą górnej piaszczystej gliny zwałowej (jednostka ŁS IV; ryc. 4; tab. 1). Nowak (1969) wiązała tę glinę z fazą wierzbicy stadiału północnomazowieckiego. Badania Frankiewicza (2017) wykazały, że uważane przez Nowak $(1958,1969)$ za morenę czołową tej fazy wydłużone i wysokie wzgórza w centralnej i południowej części arkusza Serock okazały się formami akumulacji szczelinowej lub morenami martwego lodu.

Profil zamykają w stropie pokrywy osadowe, łączone przez Kucharską i Pochocką-Szwarc (2012) oraz Frankiewicza (2017) z recesją stadiału środkowego zlodowacenia warty.

\section{MATERIAL I METODY BADAŃ}

Zgodnie z metodyką poboru próbek grubożwirowych (20-60 mm) (Meyer, 1985) i średniożwirowych (4-10 mm) do badań petrograficznych (Trembaczowski, 1961, 1967; Böse, 1979, 1989; Rutkowski, 1995a, b) w 2018 r. opróbowano glinę dolną (jednostka ŁS II) i górną (jednostka ŁS IV) oraz dolną serię wodnolodowcową (jednostka ŁS I; ryc. 3, 4).

Próbki grubożwirowe i średniożwirowe oceniono pod kątem składu petrograficznego. Obecność fennoskandzkich eratyków przewodnich zbadano w próbce żwirów gruboziarnistych. Analizę petrograficzną żwirów wykonano zgodnie z zasadami metodycznymi wielu autorów, podanymi w publikacjach m.in. Górskiej (2000a, b, 2003; Górska-Zabielska, 2008). Analizę eratyków przewodnich wykonano wg Luttiga (1958) i Meyera (1983, 1985). Próbki pobierano bezpośrednio ze ścian żwirowni. Selekcję głazików pod względem wielkości wykonano z zastosowaniem sit oczkowych i skrzynkowych. Wszystkie eratyki o rozmiarach 20-60 mm rozbijano w terenie w celu uzyskania świeżego przełamu. Tak przygotowany materiał podlegał makroskopowej segregacji na typy petrograficzne $\mathrm{z}$ użyciem $10 \% \mathrm{HCl}$ i lupy o 12 -krotnym powiększeniu. Zidentyfikowane, ale wymagające porównania ze wzorcami w atlasach skał (Zandstra, 1999; Smed, 2002; Schulz, 2003; Czubla i in., 2006; Rudolph, 2012, 2017; Vinx, 2015) eratyki przewodnie oraz wszystkie skały magmowe zostały przygo- 


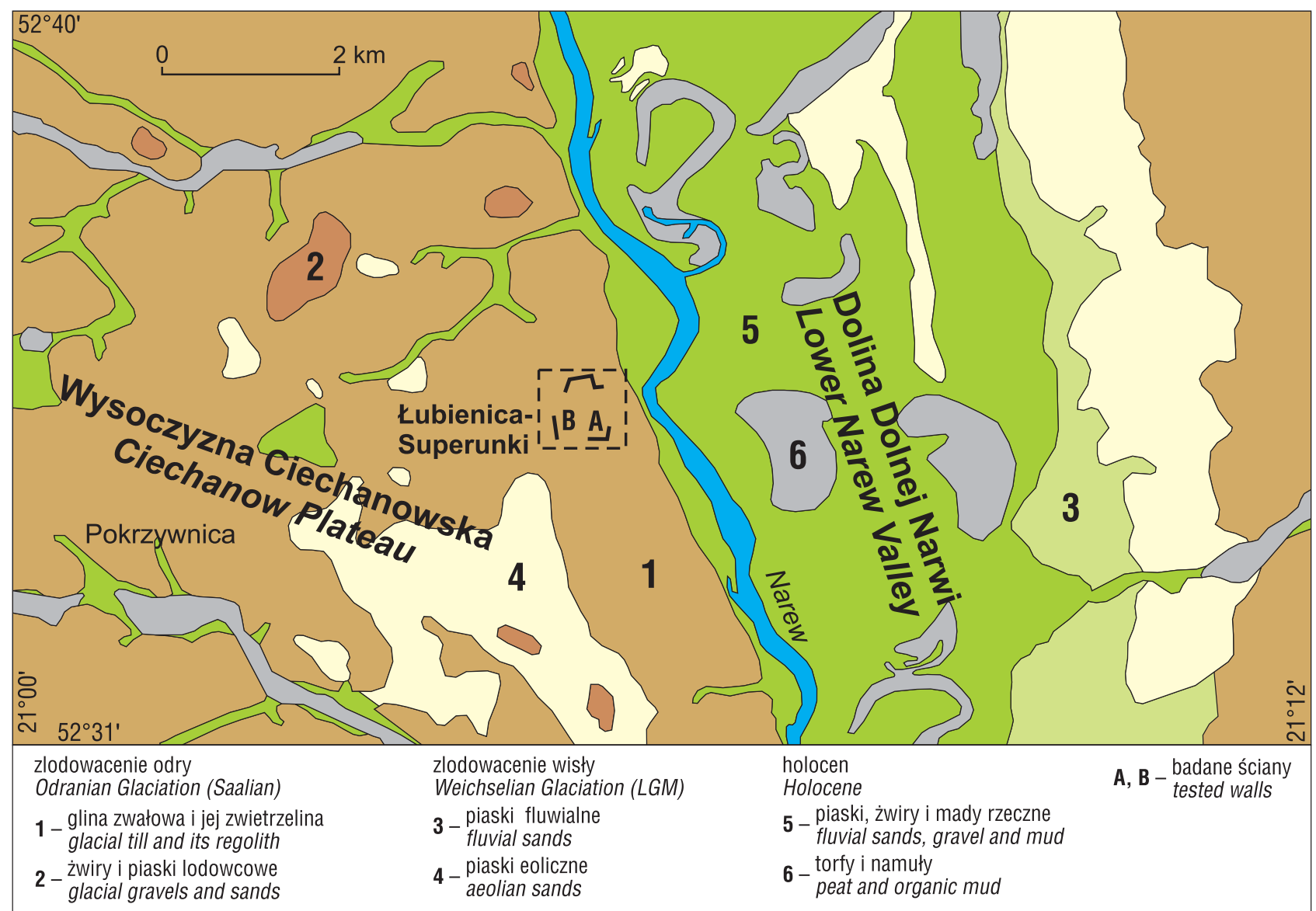

Ryc. 2. Lokalizacja badanych ścian (A i B) w żwirowni w Lubienicy-Superunkach na tle utworów powierzchniowych (https://geolog.pgi.gov.pl, SMGP, ark. Serock (450))

Fig. 2. Location of the tested walls (A and B) in the gravel pit in Eubienica-Superunki against the surface deposits (https://geolog.pgi.gov.pl, SMGP, Serock sheet (450))

towane do dalszej analizy w laboratorium. Pozostałe skały, w tym eratyki wskaźnikowe, po zliczeniu i zapisaniu w protokole terenowym, pozostawiono w terenie.

Górną serię wodnolodowcową (jednostka ŁS III) opróbowano w 2017 r. i wstępne wyniki analiz petrograficznych tych osadów zostały już opublikowane w pracy Górskiej-Zabielskiej (2017).

W toku prac terenowych i laboratoryjnych przeprowadzono analizę petrograficzną frakcji grubożwirowej:

- z dolnej serii wodnolodowcowej ŁS I (próbka ŁSu-f2) - 392 sztuki,

- z dolnej gliny lodowcowej ŁS II (ŁSu-t4) - 368,

- z górnej gliny lodowcowej ŁS IV (ŁSu-t9) - 301 .

Dla porównania w 2017 r. z górnej serii wodnolodowcowej ŁS III (ŁSu-f7) analizą tą objęto 521 żwirów gruboziarnistych. Wszystkie cztery próbki zostaną omówione w niniejszym artykule.

Odsetek zidentyfikowanych eratyków przewodnich wyniósł odpowiednio: 9,9\% (ŁSu-f2), 11,9\% (ŁSu-t4), 10,1\% (ŁSu-f7) i 18,6\% (ŁSu-t9) wymienionych powyżej skał frakcji grubożwirowej (tab. 2). Wielkości te, zgodnie z sugestiami Meyera (1983, 1985), są wystarczające, by na ich podstawie wskazać źródła alimentacji lądolodu transportującego materiał skalny na obszar Mazowsza.

Materiał średniożwirowy był analizowany w $2017 \mathrm{r}$. (próbki ŁSu-f5, ŁSu-f6 z jednostki ŁS III) i 2018 r. (próbka ŁSu-f1 z jednostki ŁS I oraz próbki ŁSu-t3 i ŁSu-t8, odpowiednio z jednostek ŁS II i ŁS IV). Każdorazowo zastosowano metodę kwartowania (Rutkowski, 1995a, b), tak aby docelowo analizą petrograficzną objąć ok. 300 ziaren frakcji 4-10 mm. Wszystkie próbki (pięć) zostaną omówione w niniejszym artykule. $W$ ich symbolach znajdują się litery: $\mathrm{t}$-dla oznaczenia gliny oraz f - dla oznaczenia osadów wodnolodowcowych.

\section{WYNIKI}

\section{Sklad petrograficzny frakcji średniożwirowej (4-10 mm)}

Analiza petrograficzna osadów średniożwirowych (4-10 mm) w Łubienicy-Superunkach wykazała, że skały krystaliczne $(\mathrm{Kr})$ są dominującym typem petrograficznym we wszystkich próbkach, niezależnie od facji osadu (ryc. 5). Większy udział procentowy tych skał w osadach wodnolodowcowych (jednostka ŁS III, próbki ŁSu-f5 i ŁSu-f6) i glinie lodowcowej (jednostka ŁS IV, próbka ŁSu-t8) niż w próbkach obu jednostek dolnych wynika z braku w tych pokładach wapieni dolnopaleozoicznych (Wp). Skały węglanowe występują wyłącznie w warstwach dolnych: wodnolodowcowej (jednostka ŁS I, próbka ŁSu-f1) i glinie lodowcowej (jednostka ŁS II, próbka ŁSu-t3). Warto zauważyć większy udział skał węglanowych w serii wodnolodowcowej (Wp1 39,24\%), aniżeli w glinie lodowcowej (Wp1 15,18\%). Udział piaskowców (Pp) jest zmienny, ale są one obecne w każdej badanej warstwie. Podobnie sytuacja wygląda z ziarnami kwarcu (Qp). Jego udział zmienia się w przedziale od 3,78 do 9,56\%. 


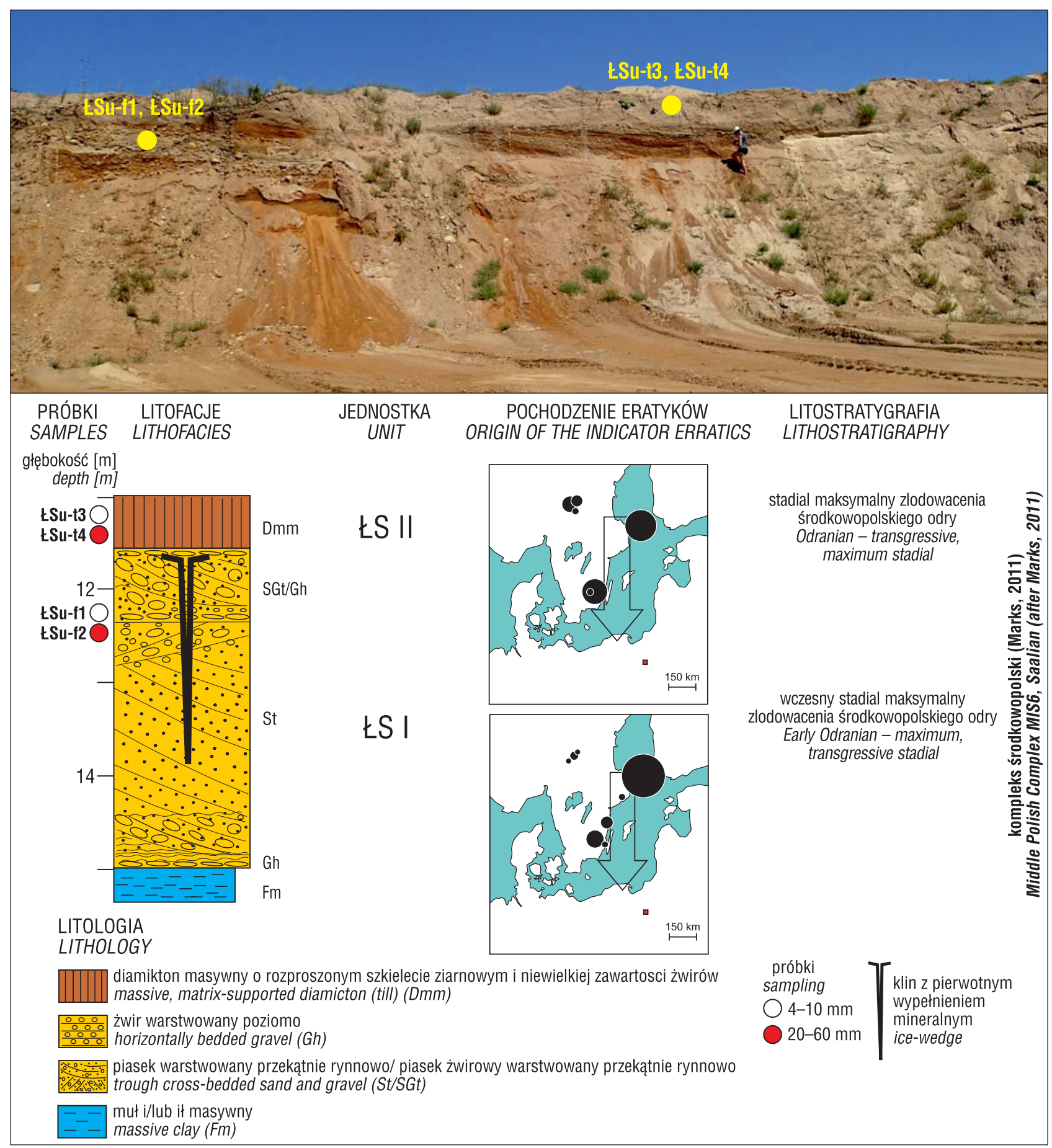

Ryc. 3. Widok ogólny na ścianę B z dolną serią wodnolodowcową (jednostka ŁS I) i dolną gliną (jednostka ŁS II) w jej stropie; zaznaczono miejsca poboru próbek (fot. E. Smolska, 2018), schematyczny profil pionowy osadów i pochodzenie oraz przedstawiono liczbę eratyków przewodnich w próbkach ŁSu-t4 i ŁSu-f2

Fig. 3. General view on wall B with units ŁS I and ŁS II at the layer top; sampling sites are shown (photo by E. Smolska, 2018), a schematic vertical profile of the sediments, and the origin and schematically presented number of indicator erratics in the ŁSu-t4 and ŁSu-f2 samples

Na podkreślenie zasługuje fakt niemal identycznych wyników analizy petrograficznej w dwóch próbkach osadów tego samego typu litogenetycznego - ŁSu-f5 i ŁSu-f6 (ryc. 5).

\section{Sklad petrograficzny frakcji grubożwirowej (20-60 mm)}

Analiza składu petrograficznego frakcji grubożwirowej (20-60 mm) wykazała, że niezależnie od litofacji osadu dominującym (ryc. 6) typem petrograficznym są skały krystaliczne ( $\mathrm{Kr})$. Udział procentowy waha się $\mathrm{w}$ granicach ok. $70 \%$ w dolnej części profilu do ok. $80 \%$ w górnej. Warto odnotować fakt, że różnica w udziale procentowym skał krystalicznych pomiędzy gliną górną (jednostka ŁS IV) i górną serią wodnolodowcową (jednostka ŁS III) jest niewielka i wynosi zaledwie $0,1 \%$. Podobnie w przypadku dolnej gliny lodowcowej (jednostka LS II) i dolnej serii wodnolodowcowej (jednostka ŁS I) - tu różnica między osadami różnych facji pod względem obecności skał krystalicznych sięga zaledwie $1 \%$. 
Tab. 1. Charakterystyka litologiczna i stratygraficzna osadów w odkrywce Łubienica-Superunki (stan 2018 r.) i rodzaje próbek pobranych do analiz petrograficznych

Table 1. Lithostratigraphical situation of the sediment profile of the Łubienica-Superunki gravel pit (2018) and the type of samples taken for petrographic analyses

\begin{tabular}{|c|c|c|c|c|}
\hline \multirow[b]{2}{*}{$\begin{array}{l}\text { Jednostka } \\
\text { Unit }\end{array}$} & \multirow[b]{2}{*}{$\begin{array}{l}\text { Litologia } \\
\text { Lithology }\end{array}$} & \multicolumn{2}{|c|}{$\begin{array}{l}\text { Korelacja wiekowa osadów MIS } 6 \\
\text { Age correlation of MIS } 6 \text { deposits }\end{array}$} & \multirow[b]{2}{*}{$\begin{array}{l}\text { Próbki: rok poboru, } \\
\text { nr, frakcja [mm] } \\
\text { Samples: } \\
\text { year of sampling, } \\
\text { No., grain size [mm] }\end{array}$} \\
\hline & & $\begin{array}{c}\text { Według Kucharskiej, } \\
\text { Pochockiej-Szwarc (2012) } \\
\text { i Frankiewicza (2017) } \\
\text { After Kucharska, Pochocka-Szwarc } \\
\text { (2012) } \\
\text { and Frankiewicz (2017) }\end{array}$ & $\begin{array}{c}\text { Propozycja autorska na podstawie } \\
\text { Marksa (2011) } \\
\text { i wykonanych badań } \\
\text { litopetro-graficznych } \\
\text { Author's proposal } \\
\text { based on Marks (2011) } \\
\text { and litho-petrographic studies } \\
\end{array}$ & \\
\hline ŁS V & $\begin{array}{l}\text { pokrywy osadowe } \\
\text { sedimentary covers }\end{array}$ & $\begin{array}{l}\text { recesja stadiału środkowego } \\
\text { zlodowacenia warty } \\
\text { recession of the middle stadial, } \\
\text { Wartanian }\end{array}$ & $\begin{array}{l}\text { późny stadiał warty } \\
\text { Late Wartanian stadial }\end{array}$ & - \\
\hline ŁS IV & $\begin{array}{l}\text { glina górna (piaszczysta) } \\
\text { upper (sandy) till }\end{array}$ & $\begin{array}{l}\text { stadiał środkowy zlodowacenia } \\
\text { warty } \\
\text { middle stadial, Wartanian }\end{array}$ & $\begin{array}{l}\text { stadiał warty, transgresywny } \\
\text { Wartanian, main, transgressive } \\
\text { stadial }\end{array}$ & $\begin{array}{c}2018 \\
\text { ŁSu-t8, (4-10) } \\
\text { ŁSu-t9, (20-60) }\end{array}$ \\
\hline ŁS III & $\begin{array}{l}\text { górna seria } \\
\text { wodnolodowcowa } \\
\text { upper fluvioglacial series }\end{array}$ & $\begin{array}{l}\text { nasuwanie się ladolodu stadiału } \\
\text { środkowego zlodowacenia warty; } \\
\text { osady transgresywne poprze- } \\
\text { dzające bezpośrednio akumulację } \\
\text { gliny zwałowej; } \\
\text { glacial advance of the middle sta- } \\
\text { dial, Wartanian; transgressive } \\
\text { sediments immediately preceding } \\
\text { the till accumulation }\end{array}$ & $\begin{array}{l}\text { wczesny stadiał warty } \\
\text { Early Wartanian, } \\
\text { pre-transgressive, maximum } \\
\text { stadial }\end{array}$ & $\begin{array}{c}2017 \\
\text { ŁSu-f5, ŁSu-f6 (4-10) } \\
\quad \text { ŁSu-f7, }(20-60)\end{array}$ \\
\hline ŁS II & $\begin{array}{l}\text { glina dolna (nieciagła) } \\
\text { lower (discontinuous) till }\end{array}$ & $\begin{array}{l}\text { starszy stadiał zlodowacenia } \\
\text { warty } \\
\text { older stadial, Wartanian }\end{array}$ & $\begin{array}{l}\text { stadiał maksymalny } \\
\text { zlodowacenia środkowopolskiego } \\
\text { odry } \\
\text { Odranian, maximum, } \\
\text { transgressive stadial }\end{array}$ & $\begin{array}{c}2018 \\
\text { ŁSu-t3, }(4-10) \\
\text { ŁSu-t4 }(20-60)\end{array}$ \\
\hline ŁS I & $\begin{array}{l}\text { dolna seria } \\
\text { wodnolodowcowa } \\
\text { (w stropie z klinem } \\
\text { peryglacjalnym) } \\
\text { lower fluvioglacial series } \\
\text { (with a wedge cast at the } \\
\text { layer top) }\end{array}$ & $\begin{array}{l}\text { nasuwanie się lądolodu starszego } \\
\text { stadiału zlodowacenia warty } \\
\text { glacial advance of the older } \\
\text { stadial, Wartanian }\end{array}$ & $\begin{array}{l}\text { wczesny stadiał maksymalny } \\
\text { zlodowacenia środkowopolskiego } \\
\text { odry } \\
\text { Early Odranian, transgressive } \\
\text { maximum stadial }\end{array}$ & $\begin{array}{c}2018 \\
\text { ŁSu-f1, (4-10) } \\
\text { ŁSu-f2, (20-60) }\end{array}$ \\
\hline
\end{tabular}

Wapienie dolnopaleozoiczne (Wp) i wapienie kredowe (Wk) występują tylko w dolnych warstwach osadów i to zarówno w glinie lodowcowej (LS I), jak i osadach wodnolodowcowych (ES II). Uwagę zwraca większy o 6,2\% udział tych skał węglanowych wśród piasków i żwirów wodnolodowcowych (ŁSu-f2) niż w glinie lodowcowej (ŁSu-t4). W obu seriach górnych nie zanotowano ani jednego okazu skały węglanowej. Kolejnym typem petrograficznym, obecnym we wszystkich zbadanych warstwach osadów, są piaskowce (Pp). Ich procentowy udział waha się od ok. 7 do 20\%. Tak odmienny udział piaskowców (trzykrotny rozrzut) wskazuje na różny pierwotny skład materiału skalnego albo na różną skalę zwietrzenia. W badanych próbkach zidentyfikowano pojedyncze żwiry gruboziarniste krzemieni (Krz 1,6-1,7\%) i kwarcu (Qp 0,6\%).

\section{Przewodnie i wskaźnikowe narzutniaki skandynawskie}

W świetle badań frakcji grubożwirowej w obu glinach lodowcowych ( $Ł S$ II i ŁS IV) i obu seriach wodnolodowcowych (ŁS I i ŁS III) należy stwierdzić, że najczęściej identyfikowano magmowe narzutniaki przewodnie reprezentujące obszar macierzysty zlokalizowany na Wyspach Alandzkich (ryc. 7). Granity i porfiry alandzkie występowały liczniej w obu jednostkach górnych ( ryc. 4). Wyłącznie $\mathrm{w}$ górnych jednostkach stwierdzono obecność czerwonych porfirów bałtyckich i jednego okazu brązowego porfiru bałtyckiego. Podobnie więcej w tych warstwach, w porównaniu z dolnymi, sklasyfikowano porfirów kwarcowych i granitów Småland. Z obszaru macierzystego Småland w południowo-wschodniej Szwecji, który reprezentują, pochodzą zidentyfikowane w badanych osadach także kwarcyty Västervik i szary granit Växjö. Udział narzutniaków przewodnich ze środkowej Szwecji, tj. z Dalarna, czyli porfirów Bredvad i Grönklitt, jest porównywalny $\mathrm{w}$ obu zbadanych jednostkach. Zidentyfikowano też jeden klast piaskowca Digerberga, będący eratykiem przewodnim pochodzenia osadowego.

Dla odmiany wyłącznie w jednostkach dolnych ( $\mathrm{SS} \mathrm{I}$ i ŁS II; ryc. 3) zidentyfikowano, pochodzace $z$ wychodni zlokalizowanych w obrębie dna Bałtyku, osadowe narzutniaki o ograniczonym znaczeniu wskaźnikowym. Były to przede wszystkim szare wapienie dolnopaleozoiczne (ok. $15-20 \%$, ryc. 6), bardzo liczne (ok. 3-4\%), w porównaniu $\mathrm{z}$ ich przeciętnym występowaniem, czerwone piaskowce jotnickie oraz pojedyncze czerwone wapienie ordowickie i wapienie Paleoporella.

Warto w tym miejscu przypomnieć, że na schematycznych mapach (ryc. 3 i 4 ) wrysowano symbolicznie w postaci kół proweniencję jedynie eratyków przewodnich. Są to skały mające wyłącznie jeden obszar alimentacyjny w Skandynawii, który opisuje się współrzędnymi geograficznymi (Lüttig, 1958). Z map nie dowiemy się zatem, czy w badanym materiale zidentyfikowano narzutniaki skandynawskie o ograniczonym znaczeniu wskaźnikowym. Ponieważ mogą one mieć więcej niż jeden obszar macie- 


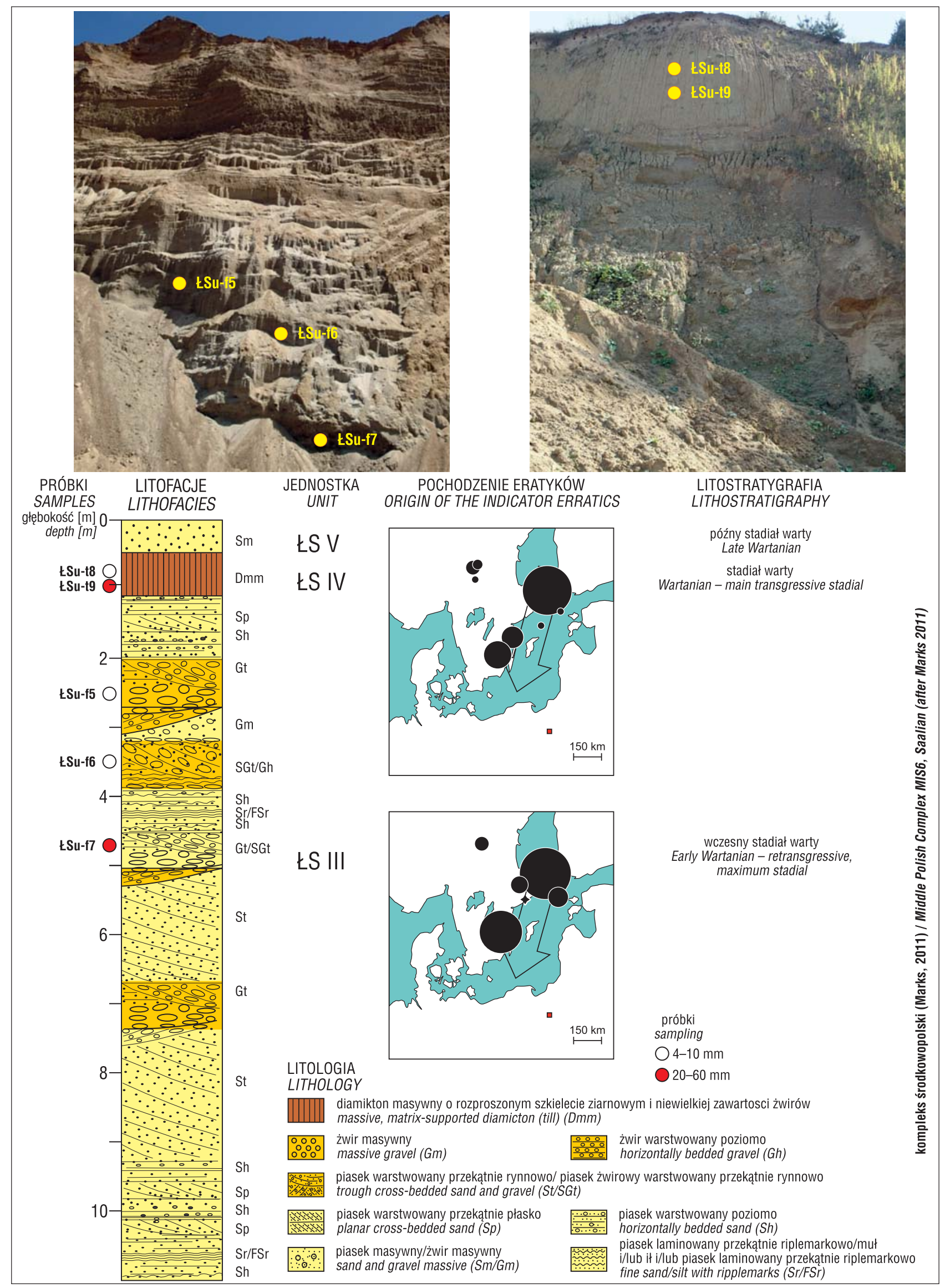

Ryc. 4. Górna seria wodnolodowcowa (jednostka ŁS III) i górna glina lodowcowa (jednostka ŁS IV), zaznaczono miejsca poboru próbek (fot. E. Smolska, 2018), schematyczny profil pionowy osadów i pochodzenie oraz przedstawiono liczbę eratyków przewodnich w próbkach ŁSu-t9 i ŁSu-f7

Fig. 4. Upper outwash sediments (unit ŁS III) and upper till (unit ŁS IV), sampling sites are shown (photo by E. Smolska, 2018), a schematic vertical profile of the sediments, and the origin and schematically presented number of indicator erratics in the $Ł S u-t 9$ and $Ł S u-f 7$ samples 
Tab. 2. Liczba narzutniaków przewodnich zidentyfikowanych w badanych osadach w Łubienicy-Superunkach Table 2. Number of indicator erratics identified in the studied sediments in Łubienica-Superunki

\begin{tabular}{|c|c|c|c|c|c|c|}
\hline \multirow{2}{*}{$\begin{array}{l}\text { Eratyk przewodni } \\
\text { Indicator erratic }\end{array}$} & \multicolumn{2}{|c|}{$\begin{array}{l}\text { Współrzędne geograficzne } \\
\text { Geographical coordinates }\end{array}$} & \multicolumn{4}{|c|}{$\begin{array}{l}\text { Nazwa próbki } \\
\text { Sample name }\end{array}$} \\
\hline & $\begin{array}{l}\text { Długość wschodnia } \\
\text { Longitude } E\end{array}$ & $\begin{array}{c}\text { Szerokość pólnocna } \\
\text { Latitude } N\end{array}$ & LSu-f2 & LSu-t4 & LSu-f7 & LSu-t9 \\
\hline $\begin{array}{l}\text { Granit alandzki, rapakiwi } \\
\text { i granitoporfir alandzki } \\
\text { Åland granite, Åland rapakivi } \\
\text { and granite-porphyry }\end{array}$ & 20 & 60 & 21 & 18 & 26 & 24 \\
\hline $\begin{array}{l}\text { Porfir bałtycki czerwony } \\
\text { Red Baltic porphyry }\end{array}$ & 21.1 & 59.1 & & & 4 & 1 \\
\hline $\begin{array}{l}\text { Porfir baltycki brunatny } \\
\text { Brown Baltic porphyry }\end{array}$ & 18.9 & 58.7 & & & & 1 \\
\hline $\begin{array}{l}\text { Granit sztokholmski } \\
\text { Stockholm granite }\end{array}$ & 18 & 59.3 & 1 & & & \\
\hline $\begin{array}{l}\text { Granit Uppsala } \\
\text { Uppsala granite }\end{array}$ & 17.5 & 59.7 & & & 3 & \\
\hline $\begin{array}{l}\text { Porfir Grönklitt } \\
\text { Grönklitt porphyry }\end{array}$ & 14.5 & 61.5 & 1 & 4 & & 3 \\
\hline $\begin{array}{l}\text { Porfir Bredvad } \\
\text { Bredvad porphyry }\end{array}$ & 13.9 & 61.4 & 2 & 8 & 2 & 8 \\
\hline $\begin{array}{l}\text { Porfir Dalarna } \\
\text { Dalarna porphyry }\end{array}$ & 14.3 & 61.3 & & 1 & & \\
\hline $\begin{array}{l}\text { Zlepieniec Digeberga } \\
\text { Digeberga conglomerate }\end{array}$ & 14 & 61 & 1 & & & \\
\hline $\begin{array}{l}\text { Kwarcyt Västervik } \\
\text { Västervik quartzite }\end{array}$ & 16.6 & 57.7 & 4 & & & 5 \\
\hline $\begin{array}{l}\text { Szary granit Växjö } \\
\text { Grey Växjö granite }\end{array}$ & 15 & 57 & & 1 & & \\
\hline $\begin{array}{l}\text { Granit Småland, } \\
\text { porfir kwarcowy Småland } \\
\text { Småland granite, } \\
\text { Småland quartz porphyry }\end{array}$ & 15.5 & 57 & 7 & 12 & 23 & 13 \\
\hline $\begin{array}{l}\text { Piaskowiec Kalmarsund } \\
\text { Kalmarsund sandstone }\end{array}$ & 16.2 & 56.4 & 2 & & & \\
\hline $\begin{array}{l}\text { Granit Filipstad } \\
\text { Filipstad granite }\end{array}$ & 13.7 & 60.6 & & & & 1 \\
\hline \multicolumn{3}{|c|}{$\begin{array}{l}\text { Eaczna liczba narzutniaków w próbce } \\
\text { Total number of erratics in a sample }\end{array}$} & 39 & 52 & 58 & 56 \\
\hline \multicolumn{3}{|c|}{$\begin{array}{l}\text { Odsetek zidentyfikowanych eratyków przewodnich w próbce } \\
\text { Percentage of indicator err. acc. to total number of erratics in a sample }\end{array}$} & 9,9 & 11,9 & 11,1 & 18,6 \\
\hline
\end{tabular}

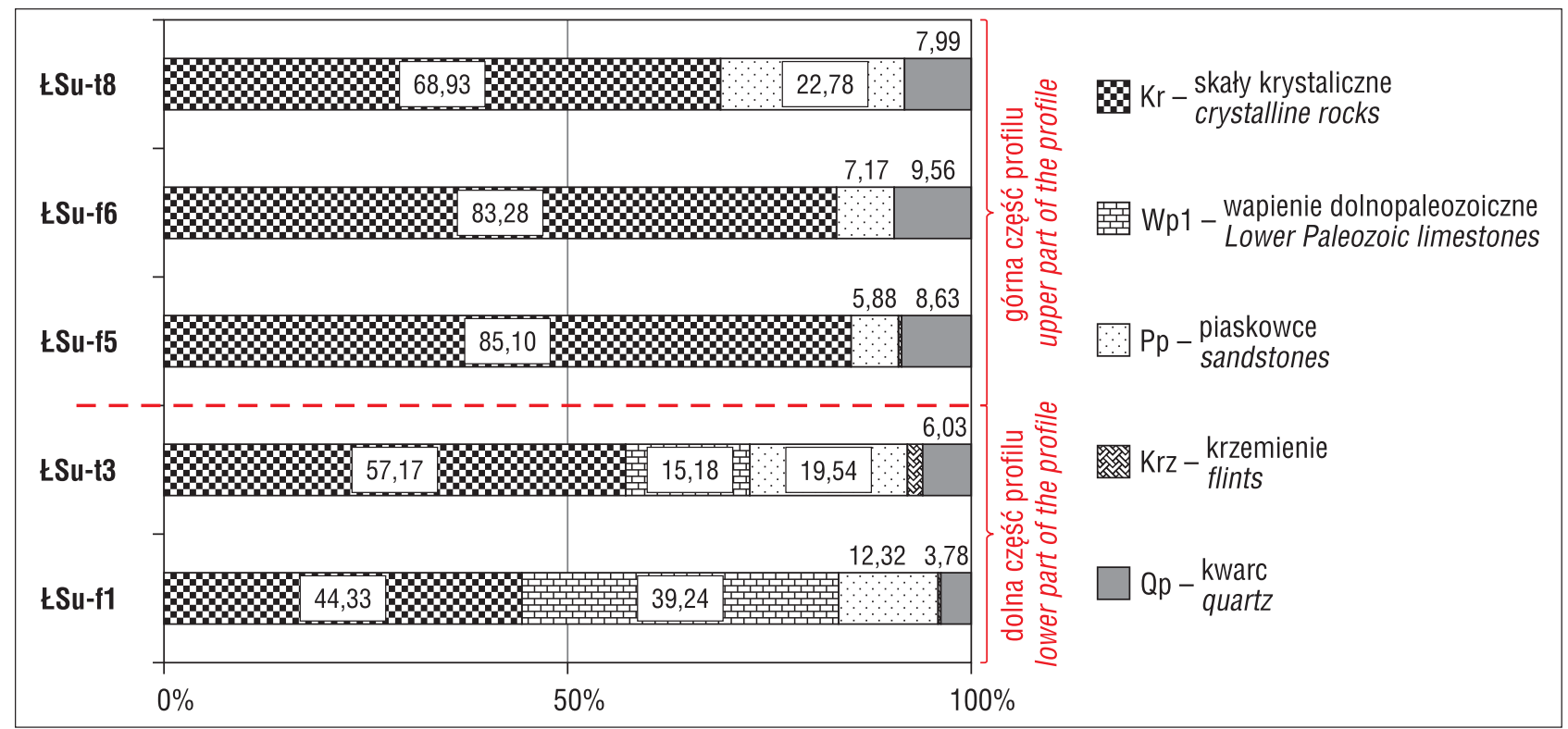

Ryc. 5. Skład petrograficzny frakcji średniożwirowej 4-10 mm osadów w Łubienicy-Superunkach

Fig. 5. Petrographic composition of $4-10 \mathrm{~mm}$ gravels in Łubienica-Superunki 


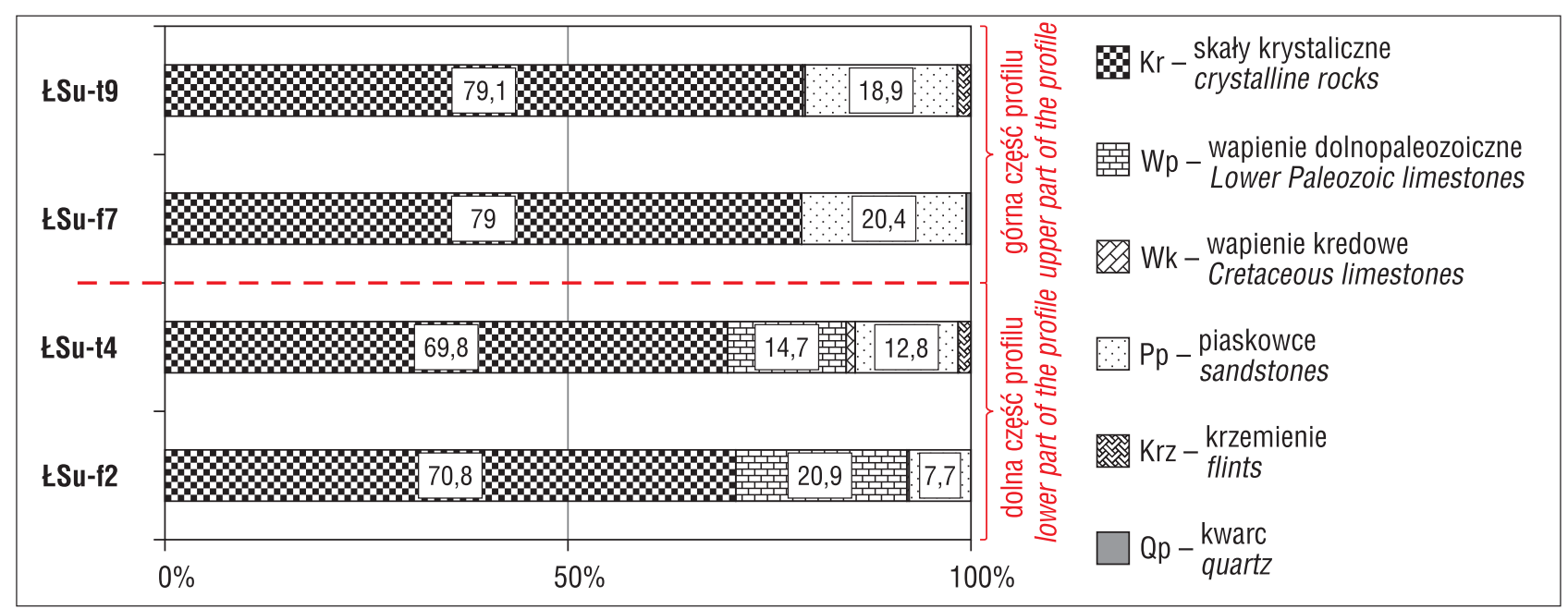

Ryc. 6. Skład petrograficzny frakcji grubożwirowej 20-60 mm osadów w Łubienicy-Superunkach

Fig. 6. Petrographic composition of $20-60 \mathrm{~mm}$ gravels in Łubienica-Superunki

rzysty, względnie obszar ten zajmuje dużą powierzchnię, nie można zwizualizować skandynawskiego miejsca pochodzenia takich narzutniaków. Konieczne jest zatem oparcie interpretacji (na rycinach w postaci strzałek) na wynikach pochodzących z kompleksowych analiz laboratoryjnych.

\section{DYSKUSJA I WNIOSKI}

Uszczegółowienie badań petrograficznych żwirów średnio- i gruboziarnistych w osadach zlodowacenia środkowopolskiego rzuca nowe spojrzenie na zagadnienie skandynawskiego pochodzenia osadów w Łubienicy-Superunkach.

Wcześniejsze badania petrograficzne żwirów spiaszczonej górnej gliny lodowcowej (Balzam, 1958, por. Nowak, 1969), wiązanej przez Frankiewicza (2017) ze środkowym stadiałem zlodowacenia warty, wykazały we frakcji powyżej $2 \mathrm{~mm}$ 40-70\% skał magnetycznych (prawdopodobnie Balzam (1958) miał na myśli skały magmowe) i metamorficznych, 22-55\% wapieni oraz 2-8\% kwarcytów. Autor w badanych próbkach nie stwierdził obecności piaskowców ani ziaren kwarcu.

Powyższe wyniki są nieporównywalne z wynikami uzyskanymi przez autorki, bo wydzielane grupy petrograficzne są różne. Można je traktować tylko w kategoriach poglądowych.

Z wynikami analiz zrealizowanych w ramach SMGP ark. Serock (nr 450; Frankiewicz, 2017) i ark. Wyszków (nr 451; Kucharska, Pochocka-Szwarc, 2012) można porównać wyłącznie wyniki analiz petrograficznych żwirów średnioziarnistych glin lodowcowych, które są omawiane w tym artykule. Podnoszone wątpliwości, związanie z analizowanymi innymi przedziałami frakcjonalnymi żwirów średnich (4/5-10 mm), zostały szczegółowo wyjaśnione przez Lipkę (2012). Instrukcja SMGP nie przewiduje analizy petrograficznej żwirów średnioziarnistych w osadach wodnolodowcowych, a także żadnej żwirów gruboziarnistych.

Skład petrograficzny żwirów średnioziarnistych dolnej gliny lodowcowej charakteryzuje się przewagą wapieni paleozoicznych nad skałami krystalicznymi zarówno w granicach ark. Serock (badania Marcinkowskiego, 2017), jak i ark. Wyszków (badania Zabielskiego, 2006). Na podstawie uśrednionych współczynników petrograficznych Marcinkowski (2017) określa tę glinę jako litotyp W1 zlodowacenia warty, a Zabielski (2006) koreluje ją ze zlodowaceniem środkowopolskim (stadiałem) odry. Nasze badania w Łubienicy-Superunkach wskazują na prawie czterokrotnie większy udział skał krystalicznych niż wapieni w tej glinie lodowcowej (ŁS II: ŁSu-t3; ryc. 5). Taka zależność, choć dużo słabsza, cechuje osady wodnolodowcowe ( $\mathrm{SS}$ I: ŁSu-f1) podścielające glinę. Zwraca uwagę większy udział skał węglanowych aniżeli odpornych na wietrzenie skał krystalicznych w osadach akumulacji wodnolodowcowej, w stosunku do gliny lodowcowej.

Górna glina lodowcowa, zbadana przez Zabielskiego (2006) na obszarze obejmującym ark. Wyszków (Kucharska, Pochocka-Szwarc, 2012), cechuje się niewielką przewagą wapieni dolnopaleozoicznych nad skałami krystalicznymi. W świetle przeprowadzonych badań autor koreluje ją ze zlodowaceniem środkowopolskim (stadiałem) warty. Również Marcinkowski (2017) stwierdza przewagę wapieni dolnopaleozoicznych nad skałami krystalicznymi i na podstawie współczynników petrograficznych zalicza tę glinę, leżącą w granicach arkusza Serock, do litotypu W2 zlodowacenia warty. Przeprowadzone przez autorki badania petrograficzne w Łubienicy-Superunkach wskazują na całkowity brak skał węglanowych wśród żwirów frakcji 4-10 $\mathrm{mm}$ pochodzących zarówno z górnej gliny lodowcowej (ŁS IV: próbka ŁSu-t8), jak i z podścielających ją serii wodnolodowcowych (ŁS III: próbki ŁSu-f5, ŁSu-f6). Wyniki analiz odwapnionych próbek osadów średniożwirowych, badane w szerszym przedziale frakcjonalnym, w obu górnych jednostkach nie mogą, ze względów metodycznych, być bezpośrednio korelowane $\mathrm{z}$ wynikami analiz Zabielskiego (2006) i Marcinkowskiego (2017). Te ostatnie można jedynie traktować jako tło do zagadnień korelacyjnych.

Pobrane w 2017 r. dwie próbki żwirów średnioziarnistych (ŁSu-f5, ŁSu-f6) z tej samej górnej serii wodnolodowcowej (ŁS III) cechuje niemal identyczny procentowy udział żwirów należących do danego typu petrograficznego. Takie podobieństwo można wykorzystać jako narzędzie we wnioskowaniu chronostratygraficznym, co zostało szeroko opisane w literaturze (np. Lüttig, 1991, 2005; Böse, 


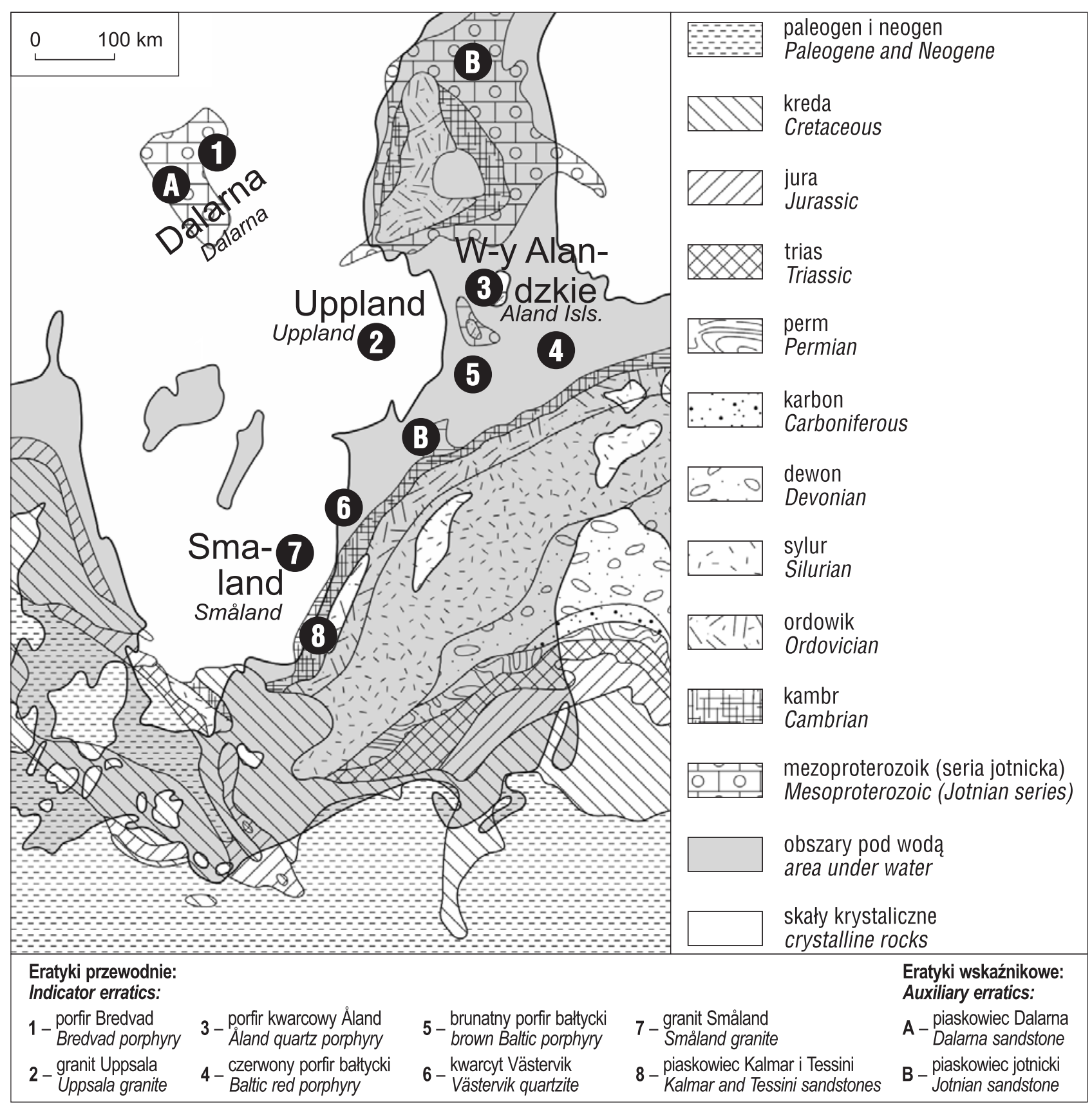

Ryc. 7. Lokalizacja wychodni eratyków przewodnich oraz symboliczna lokalizacja wychodni eratyków wskaźnikowych zidentyfikowanych w osadach żwirowni Łubienica-Superunki (na podstawie Górskiej-Zabielskiej, 2015)

Fig. 7. Location of the outcrops of indicator erratics and symbolic location of the outcrops of erratics of limited indicative significance identified in the Łubienica-Superunki gravel pit (after Górska-Zabielska, 2015)

Górska, 1995; Meyer, 1998, 2000, 2005; Czubla, 2001; Czubla i in., 2013, 2019). W przypadku podobnych cech petrograficznych żwirów dla różnych jednostek osadowych, ale w obrębie jednego profilu osadowego, jednostki te przyporządkowuje się do tego samego epizodu glacjalnego. Takie postępowanie zastosowano np. w przypadku różnowiekowych glin lodowcowych plejstocenu w Ujściu nad Notecią (Böse, Górska, 1995; Górska, 2000b).

Badania petrograficzne są użytecznym narzędziem pozwalającym ustalić pozycję stratygraficzną osadów w żwirowni Łubienicy-Superunkach. Na ich podstawie można odróżnić dwie jednostki osadowe dolne (ŁS I, ŁS II) od górnych (ŁS III, ŁS IV). Różnicuje je obecność skał węglanowych w obu jednostkach dolnych i całkowity ich brak w górnych. Najpewniej jest to przejaw zwietrzenia skał węglanowych w warstwie przypowierzchniowej osadów, choć nie można też wykluczyć odmiennych warunków reologicznych w stopie lądolodu obu nasunięć. Lądolód starszy mógł się przemieszczać po wychodniach skał osadowych dna Bałtyku. Brak wapieni dolnopaleozoicznych w obu jednostkach górnych może świadczyć, że na obszarze ich fennoskandzkich wychodni mogła się znajdować część lądolodu o zimnej stopie, przytwierdzonej do podłoża i niemającej zdolności egzaracyjnych. Poszerzenie w przyszłości badań o nowe próbki osadów z odsłonięcia w Łubienicy-Superunkach powinno rozwiać tę wattpliwość.

Zarówne nasze, jak i inne badania (Górska-Zabielska, 2008; Lipka, 2012; Górska-Zabielska, Wachecka-Kotkowska, 2015) wskazują, że udział procentowy typów petrograficznych żwirów, wiązanych $\mathrm{z}$ tym samym nasunięciem 
lądolodu, nie różni się wyraźnie pomiędzy gliną lodowcową a osadami wodnolodowcowymi. Na tej podstawie sugeruje się zastąpić żmudny pobór żwirów gruboziarnistych do tej analizy w glinie lodowcowej, a zastapić ich dużo łatwiejszym i szybszym poborem z warstwy piaszczysto-żwirowej.

Przeprowadzone analizy petrograficzne wykazały także, że to nie typ litologiczny determinuje obecność lub brak skał węglanowych w inwentarzu żwirów. Skały te były obecne zarówno w dolnej glinie lodowcowej (próbka ŁSu-t3; ryc. 5), jak i w dolnej serii wodnolodowcowej (ŁSu-f1). Uważamy, że występowanie skał węglanowych niezależnie od typu litogenetycznego, z których pochodzą, jest następstwem przemieszczania się lądolodu po wychodnich paleozoiku dolnego w dnie Bałtyku właściwego. W literaturze znane są przykłady świadczące o przydatności osadów wodnolodowcowych w analizach petrograficznych (np. Jurgaitis, 1984; Mikalajskas, 1985; Lüttig, 1991, 1999, 2005). Watek ten, z przywołaniem odpowiednich źródeł, jest szeroko omówiony w pracy Górskiej-Zabielskiej (2008). Brak skał węglanowych lub tylko częściowe odwapnienie w osadach lodowcowych jest w świetle literatury (m.in. Czubla, 2001; Woźniak, 2004; Woźniak i in., 2009; Czubla i in., 2013; Strzelecki, 2019) wynikiem ich postdepozycyjnego zwietrzenia chemicznego.

Odzwierciedleniem wyników analiz petrograficznych żwirów średnioziarnistych są wyniki takich analiz we frakcji żwirów grubych, z uwzględnieniem znanych z literatury (m.in. Schulz, 1999; Górska, 2000b) prawidłowości w procentowym udziale typów petrograficznych między obiema frakcjami. Żwiry obu jednostek dolnych (ŁS I, ŁS II) zawieraja wapienie paleozoiczne $(\mathrm{Wp})$. Ich procentowy udział jest większy w osadach, które podlegały segregacji wodnej (ŁSu-f2), niż w glinie lodowcowej (ŁSu-t4). Obie jednostki górne (ŁS III, ŁS IV) są tych skał pozbawione. Procentowe udziały żwirów poszczególnych typów petrograficznych w różniących się typach litogenetycznych są niemal identyczne (ŁSu-f7, ŁSu-t9; ryc. 6).

Narzutniaki skandynawskie frakcji 20-60 mm świadczą o zdolnościach egzaracyjnych lądolodu obu nasunięć na obszarze Wysp Alandzkich (ryc. 7). Lądolód starszy przemieszczał się po wychodniach dolnopaleozoicznych dna Bałtyku (ryc. 7). Do podobnych konkluzji, na podstawie badań osadów środkowej Polski, doszli ostatnio Czubla i in. (2019) oraz Strzelecki (2019), którzy stwierdzaja. że charakterystyczną cechą zlodowacenia odry w zapisie zespołów narzutniaków przewodnich i o ograniczonym znaczeniu wskaźnikowym jest duży udział skał alandzkich i bałtyckich oraz stosunkowo mniejszy z pd.-wsch. i środkowej Szwecji. W odróżnieniu, lądolód nasunięcia młodszego, jaki dotarł do Łubienicy-Superunek, bardziej egzarował wychodnie pd.-wsch. Szwecji. Z pewnością musiał także erodować wychodnie skał bałtyckich, tyle że nie ma po nich już dziś w badanych osadach żadnego śladu. W zespołach narzutniaków przewodnich wszystkich jednostek występują eratyki ze środkowej Szwecji. Ich ilość, choć dużo mniejszą od wyżej wymienionych, należy dla porządku odnotować.

Podobne wyniki, świadczące o dwudzielności pod kątem cech litologiczno-petrograficznych osadów przypowierzchniowych, uzyskano w strefie marginalnej i na zapleczu maksymalnego zasięgu stadiału warty, odpowiednio na Wyżynie Przedborskiej, Wzgórzach Radomszczańskich i Równinie Piotrkowskiej (Górska-Zabielska, Wachecka-Kotkowska, 2015; Wachecka-Kotkowska, 2015). W glinie lodowcowej strefy marginalnej stadiału odry frakcja żwirowa zawierała wapienie dolnopaleozoiczne, natomiast frakcja żwirowa gliny lodowcowej zaplecza, wiązanej ze stadiałem warty MIS 6, była tych skał pozbawiona.

\section{PODSUMOWANIE}

Analiza petrograficzna żwirów średnio-i gruboziarnistych odsłaniających się w dwóch glinach lodowcowych i dwóch seriach osadów wodnolodowcowych, wiązanych ze zlodowaceniem środkowopolskim MIS6, na pograniczu Doliny Dolnej Narwi i Wysoczyzny Ciechanowskiej Niziny Północnomazowieckiej, wykazała następujące prawidłowości:

- zróżnicowanie petrograficznie wszystkich czterech jednostek osadowych jest dużo większe pomiędzy jednostkami dolnymi (ŁS I i ŁS II) i górnymi (ŁS III i ŁS IV) niż pomiędzy odmiennymi typami litogenetycznymi jednostek dolnych i jednostek górnych;

- na tej podstawie sugerujemy skorelować dwie dolne jednostki (ŁS I i ŁS II) z jednym nasunięciem lądolodu oraz dwie górne jednostki ( ŁS III i ŁS IV) z innym odrębnym nasunięciem lądolodu;

- podobieństwo w udziale procentowym typów petrograficznych (przy jednoczesnym braku tego samego typu), niezależnie od typu litogenetycznego osadów, pozwala rozważyć rezygnację ze żmudnego opróbowania gliny lodowcowej i skupienie się na dużo szybszej analizie petrograficznej osadów wodnolodowcowych krótkiego transportu, wiązanych z tym samym lądolodem; prawidłowość ta manifestuje się wyraźniej wśród żwirów gruboziarnistych;

- dolną glinę lodowcową (ŁS II) i dolną serię osadów wodnolodowcowych (ŁS I) cechuje obecność wapieni paleozoicznych; ich procentowy udział jest większy, niezależnie od badanej frakcji, w osadach środowiska wodnolodowcowego, z którym wiąże się większe oddziaływanie niszczące na detrytus skalny;

- obie jednostki osadowe górne (ŁS III i ŁS IV) w badanych obu frakcjach są pozbawione skał węglanowych, co najpewniej jest następstwem postsedymentacyjnego zwietrzenia chemicznego osadów;

- we wszystkich badanych jednostkach osadów dominują skały krystaliczne zarówno we frakcji średnio-, jak i grubożwirowej;

- udział procentowy ziaren kwarcu jest zauważalnie większy wśród żwirów drobniejszych.

Korzystając z dokonanego już wcześniej skorelowania wiekowego osadów omawianego obszaru badawczego oraz na podstawie innych ponadregionalnych badań (Marks, 2011; Wachecka-Kotkowska, 2015), można obecnie skłaniać się ku tezie, że ta część lądolodu stadiału maksymalnego odry (kompleksu środkowopolskiego), która dotarła po obszar badań, przemieszczała się po wychodniach alandzkich i najbliższego otoczenia, dna Bałtyku właściwego, ledwie zahaczając o dzisiejsze wybrzeże południowo-wschodniej Szwecji (ryc. 3 i 4). Lądolód młodszy, stadiału warty tego zlodowacenia, rozwinął swe zdolności egzaracyjne głównie na obszarze Wysp Alandzkich oraz środkowej i pd.-wsch. Szwecji. Przemieszczając się dalej na po- 
łudnie, musiał zerodować skały wychodni dna Bałtyku. Brak skał węglanowych w badanych osadach jest najpewniej efektem chemicznego zwietrzenia osadów obu jednostek górnych. O tym, że miało ono w Łubienicy-Superunkach charakter lokalny, świadczą wcześniejsze wyniki analiz petrograficznych osadów powierzchniowych występujących na obszarach sąsiednich.

Dziękujemy Prof. Leszkowi Marksowi, anonimowemu Recenzentowi oraz Redaktorowi Naczelnemu Przeglądu Geologicznego dr. hab. Wiesławowi Treli za wnikliwe uwagi i komentarze. Badania sfinansowano ze środków statutowych macierzystych uczelni autorek.

\section{LITERATURA}

BER A., LINDNER L., MARKS L. 2007 - Propozycja podziału stratygraficznego czwartorzędu Polski. Prz. Geol., 55 (2): 115-118.

BÖSE M. 1979 - Die geomorphologische Entwicklung im westlichen Berlin nach neueren stratigraphischen Untersuchungen. Berl. Geograph. Abhandlung., 28.

BÖSE M. 1989 - Methodisch-stratigraphische Studien und paläomorphologische Untersuchungen zum Pleistozän südlich der Ostsee. Berl. Geograph. Abhandlung., 51.

BÖSE M., GÓRSKA M. 1995 - Lithostratigraphical studies in the outcrop at Ujście, Toruń-Eberswalde Pradolina, western Poland. Eiszeitalter und Gegenwart, 45: 1-14

CZUBLA P. 2001 - Eratyki fennoskandzkie w Polsce Środkowej i ich znaczenie stratygraficzne. Acta Geogr. Lodz., 80.

CZUBLA P. 2015 - Eratyki fennoskandzkie w osadach glacjalnych Polski i ich znaczenie badawcze. Wyd. UŁ, Łódź.

CZUBLA P., FORYSIAK J., TWARDY J. 2013 - Diamicton in Besiekierz (Central Poland) - how to avoid misinterpretation of superposition in Quaternary geology. Geol. Quart., 57 (4): 629-636.

CZUBLA P., GAŁAZKA D., GÓRSKA M. 2006 - Eratyki przewodnie w glinach morenowych Polski. Prz. Geol., 54 (4): 352-362.

CZUBLA P., TERPIŁOWSKI S., ORŁOWSKA A., ZIELIŃSKI P ZIELIŃSKI T., PIDEK I.A. 2019 - Petrographic features of tills as a tool in solving stratigraphical and palaeogeographical problems - A case study from Central-Eastern Poland. Quatern. Inter., 501A: 45-58; doi: https://doi. org/10.1016/j.quaint.2017.08.028

DĄBSKI M., ZAWADZKA-PAWLEWSKA U., GREŃ K. 2017 - Struktury peryglacjalne na stanowisku Łubienica Superunki (Wysoczyzna Ciechanowska) - wstępne wyniki badań. Landform Analysis, 33: 17-24. FRANKIEWICZ A. 2017 - Materiały robocze do Szczegółowej Mapy Geologicznej Polski w skali 1 : 50 000, ark. Serock. Państw. Inst. Geol., Warszawa.

GAŁĄZKA D. 2004 - Zastosowanie makroskopowych badań eratyków do określenia stratygrafii glin lodowcowych środkowej i północnej Polski. Praca doktorska. Arch. Wydz. Geol. UW, Warszawa.

GIRIAT D., SMOLSKA E., WOŹNIAK B. 2017 - Cechy sedymentologiczne osadów wodnolodowcowych w żwirowni Łubienica-Superunk (SE część Wysoczyzny Ciechanowskiej). Landform Analysis, 33: 25-36. GÓRSKA M. 2000a - Narzutniaki skandynawskie - metodyka badań i interpretacja. Analiza eratyków ze stanowiska w Koczerach koło Drohiczyna. [W:] Terpiłowski S. (red.), Warsztaty terenowe „Osady, struktury deformacyjne i formy warciańskiej strefy glacjomarginalnej na Nizinie Podlaskiej". Lublin-Mielnik, 25-29.09.2000 r.: 67-72.

GÓRSKA M. 2000b - Wybrane właściwości petrograficzne vistuliańskich moren dennych środkowej i zachodniej Wielkopolski oraz ich znaczenia dla oceny dynamiki ostatniego lądolodu. Prace PTPN, 28 GÓRSKA M. 2002 - Petrografia osadów akumulacji lodowcowej i wodnolodowcowej Pojezierza Drawskiego. Badania fizjograficzne nad Polską Zachodnią, 53 (A): 29-42.

GÓRSKA M. 2003 - Analiza petrograficzna narzutniaków skandynawskich. [W:] Harasimiuk M., Terpiłowski S. (red.), Analizy sedymentologiczne osadów glacigenicznych. Wyd. UMCS, Lublin: 23-31.

GÓRSKA M. 2006 - Narzutniaki przewodnie z Sobolewa (sandr suwalsko-augustowski). Pr. Kom. Paleogeogr. Czwartorz. PAU, 3: 209-212.

GÓRSKA-ZABIELSKA M. 2008 - Fennoskandzkie obszary alimentacyjne osadów akumulacji glacjalnej i glacjofluwialnej lobu Odry. Wyd Nauk. UAM, Geografia, 78.

GÓRSKA-ZABIELSKA M. 2017 - Wstępne wyniki analizy petrograficznej osadów w żwirowni Łubienica-Superunki. Landform Analysis, 33: 3-9.

GÓRSKA-ZABIELSKA M., WACHECKA-KOTKOWSKA L. 2014 Petrographical analysis of Warthian fluvioglacial gravels as a tool to tra- ce the source area - a case study from central Poland. Geologos, 20 (3): 183-199.

GÓRSKA-ZABIELSKA M., WACHECKA-KOTKOWSKA L. 2015 Petrografia żwirów i eratyki przewodnie w osadach wodnolodowcowych jako przesłanki wnioskowania na temat źródeł i kierunków transportu materiału w obszarze między Piotrkowem Trybunalskim, Radomskiem a Przedborzem ('środkowa Polska). Acta Geogr. Lodz., 103: 57-77.

JURGAITIS A. 1984 - Litogenez fluwioglacjalnych otłożenii obłastii poslednego materikowogo oledenija. Litowskij Nauczno-Issledowatelskij Geologorazwiedocznyj Institut. Moskwa, Wyd. Niedra.

KENIG K. 1998 - Petrograficzne podstawy stratygrafii glin morenowych Polski północno-wschodniej. Biul. Państw. Inst. Geol., 380.

KUCHARSKA M., POCHOCKA-SZWARC K. 2012 - Objaśnienia do SMGP, ark. Wyszków (451). Państw. Inst. Geol., Warszawa.

LIPKA E. 2012 - Zróżnicowanie cech petrograficznych osadów polodowcowych na Wysoczyźnie Lubuskiej. Praca doktorska. Arch. Inst. Geoekol. i Geoinf. UAM, Poznań.

LÜTTIG G. 1958 - Methodische Fragen der Geschiebeforschung. Geol. Jahrbuch, 75: 361-418.

LÜTTIG G. 1991 - Erratic boulder statistics as a stratigraphic aid Examples from Schleswig-Holstein. Newsletter on Stratigraphy, 25 (2): $61-74$.

LÜTTIG G. 1997 - Das geröllanalytisch-morphometrische Psammit-Psephit-Diagramm. Leipziger Geowissenschaften, 5: 9-23.

LÜTTIG G. 1999 - Geschiebestatistische Anmerkungen zur Quartärstratigraphie des nordischen Vereisungsgebietes. Eiszeitalter u. Gegenwart, 49: 144-163.

LÜTTIG G. 2004 - Ergebnisse geschiebestatistischer Untersuchungen im Umland von Hamburg. Archiv für Geschiebekunde, 3 (8/12): 729-746.

LÜTTIG G. 2005 - Geschiebezählungen im westlichen Mecklenburg. Archiv für Geschiebekunde, 4 (9): 569-608.

MARCINKOWSKI B. 2017 - Badania litologiczno-petrograficzne dla Szczegółowej Mapy Geologicznej Polski w skali 1: 50 000, ark. Serock (450). Państw. Inst. Geol., Warszawa.

MARKS L. 2011 - Quaternary Glaciations in Poland. [W:] Ehlers J., Gibbard P.L., Hughes P.D. (red.), Quaternary Glaciations - Extent and Chronology, a closer look. Developmen. Quatern. Sci., 15: 299-303.

MARKS L., KARABANOV A., NITYCHORUK J., BAHDASARAU M., KRZYWICKI T., MAJECKA A., POCHOCKA-SZWARC K., RYCHEL J., WORONKO B., ZBUCKI Ł., HRADUNOVA A., HRYCHANIK M., MAMCHYK S., RYLOVA R., NOWACKI Ł., PIELACH M. 2016 Revised limit of the Saalian ice sheet in central Europe. Quatern. Inter., 478: 47-59; dOI: http://dx.doi.org/10.1016/j.quaint.2016.07.043

MEYER K.-D. 1983 - Indicator pebble and stone count methods. [W:] Ehlers J. (red.), Glacial deposits in North-West Europe, Balkema, Rotterdam: $275-287$.

MEYER K.-D. 1985 - Zur Methodik und über den Wert von Geschiebezählungen. Der Geschiebesammler, 19 (2/3): 75-83.

MEYER K.-D. 1998 - Geschiebekundlich-stratigraphische Untersuchungen in der südlichen Lüneburger Heide. Mitt. Geol. Inst. Univ. Hannover, 38: 178-188.

MEYER K.-D. 2000 - Geschiebekundlich-stratigraphische Untersuchungen im Hannoverschen Wendland (Niedersachsen). Brandenburgische Geowiss. Beitr. 7 (1/2): 115-125.

MEYER K.-D. 2005 - Zur Stratigraphie des Saale-Glazials in Niedersachsen und zu Korrelationsversuchen mit Nachbargebieten. Eiszeitalter und Gegenwart, 55: 25-42.

MIKALAJSKAS A.P. 1985 - Fluwioglacjalnyje rawniny Litwy. Akademija Nauk Litowskoj CCR, Otdeł Geografii. Wilnius „Mokslac”.

NITYCHORUK J., ZBUCKI Ł., RYCHEL J., WORONKO B., MARKS L. 2018 - Extent and dynamics of the Saalian ice-sheet margin in Neple, eastern Poland. Bull. Geol. Soc. Finl., 90: 185-198; https://doi.org/10.$17741 /$ bgsf/90.2.004

NOWAK J. 1958 - Szczegółowa Mapa Geologiczna Polski 1 : 50 000, ark. Serock. Inst. Geol. Warszawa.

NOWAK J. 1969 - Objaśnienia do Szczegółowej Mapy Geologicznej Polski, ark. Serock (N34-127A). Wyd. Geol., Warszawa.

RUDOLPH F. 2012 - Strandsteine. Sammeln und Bestimmen von Steinen an der Ostseeküste, $11^{\text {th }}$ edn. Wachholtz, Neumünster. RUDOLPH F. 2017 - Das große Buch der Strandsteine. Die 300 häufigsten Steine an Nord- und Ostsee. Wachholtz Murmann Publishers, Neumünster.

RUTKOWSKI J. 1995a - Badania petrograficzne żwirów. [W:] Mycielska-Dowgiałło E., Rutkowski J. (red.), Badania osadów czwartorzedowych. Wybrane metody i interpretacja wyników. Wydz. Geogr. i Studiów Region. UW: 133-150.

RUTKOWSKI J. 1995b - Badania uziarnienia osadów bardzo gruboziarnistych. [W:] Mycielska-Dowgiałło E., Rutkowski J. (red.), Badania osadów czwartorzędowych. Wybrane metody i interpretacja wyników. Wydz. Geogr. i Studiów Region. UW: 106-114. 
SCHULZ W. 1996 - Zur Bedeutung der Korngröße bei Geschiebezählungen. Der Geschiebesammler, 29 (3): 91-102.

SCHULZ W. 2003 - Geologischer Fuehrer fuer den norddeutschen Geschiebesammler. CW Verlagsgruppe Schwerin.

SMED P. 2002 - Steine aus dem Norden. Geschiebe als Zeugen der Eiszeit in Norddeutschland. Gebrüder Borntraeger. Berlin, Stuttgart. SMOLSKA E., GIRIAT D., WOŹNIAK B., ZAWADZKA-PAWLEWSKA U. 2018 - Wybrane cechy sedymentologiczne osadów i ich znaczenie w rozdzieleniu poziomów wodnolodowcowych w żwirowni Łubienica-Superunki (SE Wysoczyzna Ciechanowska). [W:] Kostrzewski A., Stach A., Majewski M. (red.), Geneza, litologia i stratygrafia utworów czwartorzędowych, t. VII, IGIG UAM, Poznań: 171-175.

SOLON J., BORZYSZKOWSKI J., BIDLASIK M., RICHLING A. BADORA K., BALON J., BRZEZIŃSKA-WÓJCIK T., CHABUDZIŃSKI Ł., DOBROWOLSKI R., GRZEGORCZYK I., JODŁOWSKI M., KISTOWSKI M., KOT R., KRĄŻ P., LECHNIO J., MACIAS A. MAJCHROWSKA A., MALINOWSKA E., MIGOŃ P., MYGA-PIĄTEK U., NITA J., PAPIŃSKA E., RODZIK J., STRZYŻ M., TERPIŁOWSKI S., ZIAJA W. 2018 - Physico-geographical mesoregions of Poland: Verification and adjustment of boundaries on the basis of contemporary spatial data. Geograph. Pol., 91 (2): 143-170.

STRZELECKI P.J. 2019 - The provenance of erratic pebbles from a till in the vicinity of the city of Radom, central Poland. Geology. Geophys Environ., 45 (1): 21-29.

TGL 25 232, 1971 - Fachbereichstandard Geologie: Analyse des Geschiebebestandes quartärer Grundmoränen. Blatt 1-6, Berlin TREMBACZOWSKI J. 1961 - Przyczynki do metodyki badań granulometryczno-petrograficznych utworów morenowych. Ann. Univ. M. Curie-Skłodowska, sec. B, 16 (3): 63-95.

TREMBACZOWSKI J. 1967 - Granulometryczno-petrograficzna charakterystyka glin zwałowych Wysoczyzny Konińskiej. Pr. Inst. Geol., 48: 147-162.
TYLMANN K., RINTERKNECHT V.R., WOŹNIAK P.P., BOURLES D.L., SCHIMMELPFENNIG I., ASTER TEAM 2019 - The Local Last Glacial Maximum of the southern Scandinavian Ice Sheet front: Cosmogenic nuclide dating of erratics in northern Poland. Quater. Sci. Rev., 219: 36-46.

VINX R. 2015 - Gesteinsbestimmung im Gelände. Springer Spektrum. WACHECKA-KOTKOWSKA L. 2015 - Rozwój rzeźby obszaru między Piotrkowem Trybunalskim, Radomskiem a Przedborzem w czwartorzędzie. Wyd. UŁ; doi: 10.13140/RG.2.1.3373.8328

WACHECKA-KOTKOWSKA L., KRZYSZKOWSKI D., MALKIEWICZ M., MIROSŁAW-GRABOWSKA J., NISKA M., KRZYMIŃSKA J., MYŚKÓW E., RACZYK J., WIECZOREK D., STOIŃSKI A., RZODKIEWICZ M. 2018 - An attempt to reconstruct the late Saalian to Plenivistulian (MIS6- MIS3) natural lake environment from the „Parchliny 2014” section, central Poland. Quatern. Int., 467: 5-25.

WOŹNIAK P.P. 2004 - Przydatność analizy litologicznej glin morenowych w badaniach geomorfologicznych stref marginalnych ostatniego zlodowacenia. Prz. Geol., 52 (4): 336-339.

WOŹNIAK P.P., CZUBLA P., WYSIECKA G., DRAPELLA M. $2009-$ Petrographic composition and directional properties of tills on the NW surroundings of the Gdańsk Bay, Northern Poland. Geologija, 51: 59-67. ZABIELSKI R. 2006 - Badania litologiczno-petrograficzne osadów plejstoceńskich. SMGP w skali 1 : 50 000, ark. Wyszków (451). Państw. Inst. Geol., Warszawa.

ZANDSTRA J.G. 1999 - Platenatlas van noordelijke kristalijne gidsgesteenten. Backhuys Publishers, Leiden.

Praca wpłynęła do redakcji 6.08.2020 r.

Akceptowano do druku 5.11.2020 r. 